\title{
The effect of roasting temperature on proximate and dietary fiber of food bar salak (Sidimpuan cultivar) fruit
}

\author{
Nurhamida Sari Siregar ${ }^{1,}$, Elisa Julianti ${ }^{1, *}$, and Jansen Silalahi ${ }^{1}$ \\ ${ }^{1}$ Department of Food Science and Technology, Faculty of Agriculture, Universitas Sumatera Utara, Jl. \\ A.Sofian no 3, Medan 20155, North Sumatera, Indonesia
}

\begin{abstract}
The Sidimpuan Salak fruit was the mascot of Padangsidimpuan City, North Sumatra, Indonesia. In this study, Salak formulates to be a high-calorie food bar. The primary elements for making food bars Salak are purple sweet potato flour, tapioca flour, and dried salak fruit. The others elements were egg whites, margarine, emulsifiers, and high glucose syrup. All elements were mixed evenly and molded into bars with a size of $3 \times 8 \times 1.5 \mathrm{~cm}$ and a weight of $50 \mathrm{~g}$. Food bars from roasted salak fruit used temperatures of 80,90 , and 100 . The results showed differences in the proximate composition, calorific value, and dietary fiber content of the food bars salak. The most increased carbohydrate, fat, and calorie content get at a roasting temperature of $80^{\circ} \mathrm{C}$, the protein and mineral content obtain most increased at a roasting temperature of $100^{\circ} \mathrm{C}$, and the most increased food fiber gets at a roasting temperature $100^{\circ} \mathrm{C}$. A high-calorie food bar Salak gets at a roasting temperature of $80^{\circ} \mathrm{C}$.
\end{abstract}

\section{Introduction}

Salacca Sumatrana was a plant from South Tapanuli, North Sumatra, Indonesia. Salacca sumatrana, known as Salak sidimpuan, was the mascot of Padang Sidempuan City, and grows a lot in West Angkola District. Salak sidimpuan was very popular because it has a sweet, sour, and slightly bitter taste, which was the trademark of Salak Sidimpuan [1].

Salak contains good nutrition for the human. Generally, Salak has a water content of about $80.1 \%$. Salak fruit flesh contains carbohydrates, fiber, protein, and low fat. The total sugar content is about $17.4 \mathrm{~g} / 100 \mathrm{~g}$ consisting of sucrose, fructose, and glucose. The amount of sugar Salak was not much different from that lychee $(17.9 \mathrm{~g} / 100 \mathrm{~g})$, mangosteen $(17.5 \mathrm{~g} / 100 \mathrm{~g})$, and sugar apples Nahng variety $(17.2 \mathrm{~g} / 100 \mathrm{~g})$. Salak fruit flesh contains sodium, magnesium, potassium and calcium, iron, manganese, zinc, copper. Vitamin $\mathrm{C}$ content is about $0.78 \mathrm{mg} / 100 \mathrm{~g}$ [2].

Usually, people consume Salak fruit in a fresh state. However, fresh fruits have a short shelf life, so that if they do not eat, they will be damaged and wasted. Damage avoiding, Salak can be processed into several processed products to increase the selling value of Salak and still contain good nutrients for the human body. Producing cakes, muffins,

\footnotetext{
* Corresponding author: elisa1@usu.ac.id
} 
cookies, and flakes from Manonjaya Salak flour can be accepted by panelists in terms of taste, color, and texture [3]. In this research, dried Salak was an ingredient in the food bar that has become the potential to be one of the high-energy and nutrient-rich foods for athletes.

The developed formula contains the most balanced protein, fat, carbohydrates, minerals, and vitamins [4] and is halal [5]. People with active lifestyles like healthy snacks, so do athletes. The trend to watch today is the manufacture of sports food with attention to mealtime management, personalization, recovery food, taste, and better health for athletes [6].

Food bars using a combination of dates and prebiotics can be a source of energy and protein and thus potentially increase power, improve performance and support the athlete's immune system by adding natural flora to the digestive tract [7]. The use of dates in food bars indicates positive acceptance and liking of consumers. Energy food bars contain sugar, fiber, and minerals with a sweet taste and have the nutrients athletes need. Dates could be an alternative to add modifications to food bars and other snacks. This food bar has the potential to be marketed as a nutrient-rich food bar, ready-to-eat snacks, desserts, and helping food producers and processors think about diversifying other foods [8].

\section{Method}

\subsection{Ingredients}

The elements for food bars formulation include dried Salak, purple sweet potato flour, tapioca flour, egg whites, margarine, emulsifiers, and high glucose syrup.

\subsection{Dry salak processing}

Salak peeled and washed with running water. Separate the flesh of the salak fruit from the seeds, then slice it into thin slices of about $0.5 \mathrm{~cm}$. Arrange the Salak slices and do not overlap in a drying container with small holes. Cover the drying container with a mosquito repellent cloth to prevent the salak from getting infected by insects. Dry the Salak in the sun for two days, using the help of a fan during the drying process. After drying, store the dried Salak in an airtight container and store it in the refrigerator.

\subsection{Food bar salak formulations}

The food bar formulation adopted the Welli [12] formulation with some modifications. The main elements of the food bar are banana pseudostem flour (EBP) and canna flour, which had changed to purple sweet potato flour, tapioca flour, and dry Salak. The addition of purple sweet potato and tapioca flour to the energy content of the bars, binders to the bar from dry Salak, and produces a food bar containing dietary fiber.

Food bar Salak processing begins by mixing 30 grams of egg white, 80 grams of glucose syrup, emulsifier, and 30 grams of margarine into a plastic bowl and mixer until the dough expands. Add 50 grams of purple sweet potato flour and 50 grams of tapioca flour to the first mixture and mix until combined, then add 100 grams of crushed dry Salak and stir until all the dough comes together and can establish. Weigh the dough weighing 50 grams and put it in a mold measuring $3 \times 8 \times 1.5 \mathrm{~cm}$. After that, the dough had steamed for 5 minutes in a pan with boiling water. Bake the food bar in the oven at $80^{\circ} \mathrm{C}$ for 40 minutes, at $90^{\circ} \mathrm{C}$ for 30 minutes, and at $100^{\circ} \mathrm{C}$ for 30 minutes. Next, the food bar is removed from the oven (microwave) and cooled for 1 hour. After cooling, the food bar is packaged using 
food-safe aluminum foil and placed in an airtight plastic container. Store food bars in the refrigerator until further analysis.

\subsection{Chemical and dietary fiber analysis of food bar salak}

Laboratory tests had carried out at the Saraswati Indo Genetech (GIS) laboratory were accredited by the National Accreditation Committee (KAN). The chemical analysis: carbohydrates by different (18-8-9 /MU/SMM-SIG), water content by gravimetric (SNI 012891-1992, point 5.1), total fat by Weibull (18-8-5/MU/SMM-SIG point 3.2.2), fat energy by calculation, protein by kjeltec (18-8-31/MU/SMM - SIG), and ash content by gravimetric (SNI 01-2891-1992, 6.1) method. Test for dietary fiber by gravimetric enzymatic (18-8-6-2/MU/SMM-SIG).

\subsection{Data analysis}

Data were analyzed using ANOVA. If the results had significantly would be continued Tukey test.

\section{Results and discussion}

The roasting temperature effects on proximate composition and dietary fiber of food bar Salak, shown in Table 1. The energy content of the food bar Salak based on different roasting temperatures resulted in the highest energy content at a temperature of $80^{\circ} \mathrm{C}$. This food bar Salak aims to develop sports food with high energy. Carbohydrate-rich sports foods such as energy bars average 25 to 35 grams of carbohydrates per serving with low protein and fat content of 0-2 grams. The total energy produced ranges from 116 to 206 kcal. Its sports food was complementary to the athlete's meal planning [9].

The moisture content at $80^{\circ} \mathrm{C}$ was lower than $90^{\circ} \mathrm{C}$ and $100^{\circ} \mathrm{C}$, which could be due to a longer roasting time at $80^{\circ} \mathrm{C}$, causing more moisture content to decrease. The protein content at $90^{\circ} \mathrm{C}$ was lower than $80^{\circ} \mathrm{C}$ and significantly different, and the highest was at $100^{\circ} \mathrm{C}$ but not differently significant from $80^{\circ} \mathrm{C}$. In another study, the higher cooking temperature of soy milk could increase the amount of crude protein, crude fiber, ash content, and carbohydrate content of soy milk. The increase in concentration was due to decreased water and fat content, causing other components increasing, and increase the nutritional content of soy milk [10].

Table 1. Proximate and dietary fiber analysis of food bar salak with different roasting temperature

\begin{tabular}{|c|c|c|c|c|}
\hline Parameter & Unit (100g) & $80^{\circ} \mathrm{C}$ & $90^{\circ} \mathrm{C}$ & $100^{0} \mathrm{C}$ \\
\hline Carbohydrate & $\%$ & $68.84 \pm 0.17^{\mathrm{a}}$ & $67.85 \pm 0.27^{\mathrm{b}}$ & $68.61 \pm 0.13^{\mathrm{ac}}$ \\
\hline Total calories & $\mathrm{kcal} / 100 \mathrm{~g}$ & $358.36 \pm 0.88^{\mathrm{a}}$ & $\begin{array}{c}348.89 \pm \\
1.00^{\mathrm{b}}\end{array}$ & $356.79 \pm 0.75^{\mathrm{ac}}$ \\
\hline $\begin{array}{c}\text { Moisture } \\
\text { content }\end{array}$ & $\%$ & $19.53 \pm 0.19^{\mathrm{a}}$ & $21.14 \pm 0.2^{\mathrm{b}}$ & $19.57 \pm 0.16^{\mathrm{ac}}$ \\
\hline Total Fat & $\%$ & $8.33 \pm 0.01^{\mathrm{a}}$ & $7.79 \pm 0.01^{\mathrm{b}}$ & $8.23 \pm 0.01^{\mathrm{c}}$ \\
\hline $\begin{array}{c}\text { Protein } \\
\text { content }\end{array}$ & $\%$ & $1.99 \pm 0.03^{\mathrm{a}}$ & $1.84 \pm 0.06^{\mathrm{b}}$ & $2.07 \pm 0.03^{\mathrm{a}}$ \\
\hline Ash content & $\%$ & $1.30 \pm 0.02^{\mathrm{a}}$ & $1.37 \pm 0.03^{\mathrm{b}}$ & $1.52 \pm 0.01^{\mathrm{c}}$ \\
\hline
\end{tabular}




\begin{tabular}{|l|l|l|l|l|}
\hline Dietary Fiber & $\%$ & $11.25 \pm 0.14^{\mathrm{a}}$ & $15.89 \pm 0.01^{\mathrm{b}}$ & $12.10 \pm 0.01^{\mathrm{c}}$ \\
\hline
\end{tabular}

Frying raw mangoes and ripe mangoes at different temperatures of $90^{\circ} \mathrm{C}$ and $120^{\circ} \mathrm{C}$ resulted in lower water content at higher frying temperatures. Moisture content $<10 \%$ is required to keep the product stable during storage. When the heating process, it was causes shrinkage of polysaccharides along with the release of water and increased moisture loss [11].

Fat content food bars increase as the moisture content decreases. Higher heating temperatures cause a decrease in moisture content [12]. The concentration of ash content of the food bar Salak was higher as the roasting temperature increased. When viewed from the water content, the lower the water content concentration, the higher the ash content in the food bar. Decreased moisture content, mineral concentration increase and improve the quality of food bars Salak.

Carbohydrate content with roasting temperature between $80^{\circ} \mathrm{C}$ and $90^{\circ} \mathrm{C}$ was significantly different, where lower temperature resulted in higher carbohydrate count. In this study, the roasting temperature of $80^{\circ} \mathrm{C}$ takes 40 minutes, at $90^{\circ} \mathrm{C}$ and $100^{\circ} \mathrm{C}$ takes 30 minutes. Although higher temperatures result in lower carbohydrate content, this could be due to longer baking times at lower temperatures, resulting in lower levels of water content. The roasting temperatures of $80^{\circ} \mathrm{C}$ and $100^{\circ} \mathrm{C}$ were not significantly different, as could be because a higher temperature would increase the water content decrease even though the cooking time was short. As can be seen in the results, there is a significant difference between $90^{\circ} \mathrm{C}$ and $100^{\circ} \mathrm{C}$ roasting.

Dietary fiber was getting lower in number along with the lower water content in the food bar. Overall, the best quality food bar is in the food bar Salak with a roasting temperature of $80^{\circ} \mathrm{C}$ for 40 minutes. The total calories produced are higher by $358 \mathrm{kcal}$ with a product weight of 100 grams. Carbohydrate concentration was high level, lower water content, and high-fat content.

\section{Conclusions}

Food bar salak formulas produce different amounts of energy with divergent carbohydrate, protein, fat, ash content, and dietary fiber content. Roasting treatment with a temperature of $80^{\circ} \mathrm{C}$ with a time of 40 minutes showed the best food bar Salak results compared to a temperature of $90^{\circ} \mathrm{C}$ and $100^{\circ} \mathrm{C}$ with a roasting time of 30 minutes. These results became the basis for formulating the next food bar Salak with different combinations of dry salak in each treatment with roasting temperatures of $80^{\circ} \mathrm{C}, 90^{\circ} \mathrm{C}$, and $100^{\circ} \mathrm{C}$ and equalized roasting time of 40 minutes.

\section{References}

1. Y. Nasution, A. Rasyidin, Yulnafatmawita, A. Saidi, Biodiversitas 20, 664-670 (2019)

2. R. Chareoansiri, R. Kongkachuichai, IJFSN 60 (2019)

3. Sumarto, D. Aprianty, R.A. Bachtiar, L. Kristiana, IOP Conf. Series: Earth and Environmental Science 102 (2018)

4. N.V. Prisukhina, L.G. Ermosh, IOP Conf. Series: Earth and Environmental Science 548 (2020) A. Mecke, I. Lee, J.R. Baker jr., M.M. Banaszak Holl, B.G. Orr, Eur. Phys. J. E 14, 7 (2004)

5. S. Aljaloud, H.L.Colleran, S.A. Ibrahim, Food and Nutrition Sciences (FNS) 11, 463480 (2020) 
6. M.A. Jal, J.M.S. Negre, P.P. Lozano, E.G. Montoya, Food Science and Nutrition (FSN) (2019)

7. G. U. Alla, L. Jithendran, International Journal of Advanced Research in Science, Engineering and Technology (IJARSET) 5(4), 5558-5570 (2018)

8. A.A. Ayad, L.L. Williams, D.A. Gad El-Rab, R. Ayivi, H.L. Colleran, S. Aljaloud, S.A. Ibrahim, Cogent Food \& Agriculture, 6 (2020)

9. J.M.M. Sanz, S.M. Puey, I. Sospedra, G. Russolillo, A. Norte, I.M. Lopes, Nutrients 12, 2403 (2020)

10. J.K. Ikya, D.I. Gernah, H.E. Ojobo, O.K. Oni, Advance Journal of Food Science and Technology (AJFST) 5(5), 543-546 (2013)

11. F. Ayustaningwarno, E.V. Ginkel, J. Vitorino, M. Dekker, V. Fogliano, R. Verkerk, Frontiers in Nutrition 7, 95 (2020)

12. Y. Welli, M. Agnes, P. Yudi, M. Yustinus, Food Research 4(3), 906-916 (2020) 